\title{
Waste Plastic as Energy Material: End-Of-Life Polymer Design
}

\author{
Neil Stacey* \\ Department of Chemical engineering, University of South Africa, South Africa
}

Submission: October 10, 2018; Published: October 16, 2018

*Corresponding author: Neil Stacey, Department of Chemical engineering, University of South Africa, South Africa, Email: stacey.neil@gmail.com

\section{Abstract}

Waste plastic poses a dire threat to life on earth and addressing this crisis must be considered to be a priority in the field of polymer science. In this piece, several approaches to waste plastic handling are discussed, with their costs, benefits and potential for sustainability briefly outlined.

Keywords: Waste plastic; Plastic pollution; Polymer; Environmental impact

\section{Introduction}

Virtually every eco-system on Earth is threatened by plastic pollution, directly or indirectly [1-6]. The persistent toxic nature of plastic once it has entered the environment means that plastic pollution is, arguably, a more severe long-term environmental threat than climate change. Polymer research must therefore consider environmental impact as an urgent priority for ensuring the survival of the polymer industry and, indeed, the human species.

It follows that polymer design philosophy must needs be more focused on end-of-life usage. This question represents a convergence of multiple fields of research, depending on which end-of-life usage case is considered most prominent. Many of the possible chemical process pathways for waste plastic are under-researched and poorly understood, leaving a significant knowledge gap in this area.

\section{Discussion}

The approaches to dealing with waste plastic can be grouped into three main categories; accumulation, complete chemical conversion, and circular economy. It is useful to classify processes into these categories based on the eventual end-location of carbon atoms. In complete chemical conversion, the carbon atoms contained within plastic are converted into $\mathrm{CO}_{2}$, which is released into the atmosphere. In waste accumulation processes, carbon atoms are kept out of the atmosphere and biosphere by way of being retained in one form or another of permanent storage. In the circular economy, waste plastic is converted back into virgin polymer, generally via pyrolysis or gasification processes.

Waste accumulation is perhaps best exemplified by the use of landfills to store plastic waste, ostensibly indefinitely. This is demonstrably a non-viable approach for two reasons; the first is that no practical storage method is stable on anything like the timeframe for bio-degradation of waste plastic and therefore storage merely delays plastic's entry into the biosphere. The second flaw is that no economic value is generated by plastic in storage and there is therefore no financial incentive involved aside from the simple need for disposal. The two approaches that can be considered genuine solutions to the problem of plastic pollution are complete chemical conversion, and the circular economy. The circular economy has received a great deal of attention as it theoretically meets the requirements for genuine sustainability. It also offers a financial incentive for the collection of plastic waste, proportional to the price of virgin polymer, making it economically attractive once the capital cost for the associated infrastructure has been met. It must be noted, however, that process inefficiencies as well as fundamental thermodynamics that energy and work must be added to this cycle in order to fully close the loop. It follows that until and unless all that energy is obtained renewably, the circular economy will not be entirely sustainable.

Complete chemical conversion is less attractive in a more obvious way; it produces waste carbon, by definition. Moreover, the most common chemical pathway for complete conversion is simple incineration, which does not generate significant revenue as the monetary value of low-grade heat is fairly low even in favorable contexts. Higher-value process pathways do exist, however. In much the same way that waste plastic can be converted into the raw materials for polymerization, it can be utilized in a wide range of chemical processes, all of which merit consideration in the drive to combat plastic waste pollution. In the current context where the majority of energy is produced from non-renewable sources, cyclic plastic processing has to be considered to have a net positive carbon footprint when one considers the energy input required for it and, similarly, one must also take into account the carbon emissions that are offset when plastic displaces another fossil fuel as an energy material. 
Most forms of plastic possess higher energy content, on a per-mass basis, than common fossil fuels such as coal. Moreover, plastics possess lower fractional carbon content than coal. Consequently, the carbon emissions of a chemical process utilizing waste plastic will tend to be significantly lower than those of the same process utilizing coal. When emissions off-set are included in the determination of overall carbon footprint, complete chemical conversion can be a net carbon-negative process provided that it provides a suitable replacement for existing fossil fuels. Meanwhile, if the carbon footprint of energy consumption is factored in, circular cycling of plastic has a net positive carbon footprint.

In the long term, a circular economy for plastic appears to be the only genuinely sustainable way to continue to produce and consume plastic products. In the short- to medium-term, however, complete chemical conversion can be argued to offer larger benefits in terms of net $\mathrm{CO}_{2}$ emissions and the associated climate damage. With new high-value process pathways being developed, such as the reduction of iron ore [7-9], complete chemical conversion is also becoming increasingly economically attractive.

It may well turn out that these two different end-of-life scenarios have disparate implications for polymer design; a polymer that is optimized for use as a reducing agent in a blast furnace at end-of-life may be quite different from one that is optimized for re-conversion into virgin polymer. It follows that determining a pathway for the future of the polymer industry is a significant multi-disciplinary task bringing together several branches of chemical and metallurgical engineering as well as environmental science.

\section{References}

1. Andrady AL (2011) Microplastics in the marine environment. Mar Pollut Bull 62(8): 1596-1605.

2. Derraik JGB (2002) The pollution of the marine environment by plastic debris: a review. Mar Pollut Bull 44(9): 842-852.

3. Laist DW (1987) Overview of the biological effects of lost and discarded plastic debris in the marine environment. Mar Pollut Bull 18(6) Supplement B: 319-326.

4. Lamb JB, Willis BL, Fiorenza EA, Couch CS, Robert Howard, et al (2018) Plastic waste associated with disease on coral reefs. Science 359(6374): 460-462.

5. Wilcox C, Sebille EV, Hardesty BD (2015) Threat of plastic pollution to seabirds is global, pervasive, and increasing. Proc Natl Acad Sci 112(38): 11899-11904.

6. Van Cauwenberghe L, Janssen CR (2014) Microplastics in bivalves cultured for human consumption. Environ Pollut 193: 65-70.

7. Polat G, Birol B, Sarıdede MN (2014) Utilization of waste polyethylene terephthalate as a reducing agent in the reduction of iron ore composite pellets. Int J Miner Metall Mater 21(8): 748-754.

8. Sinha $O$ (2015) Reduction behavior of iron ore pellets with addition of plastics along with conventional reducing agents 122 . J Metall Mater Sci 57: 167-171.

9. Stacey N (2018) Use of waste plastic as a reducing agent for iron ore

\section{Your next submission with Juniper Publishers will reach you the below assets}

- Quality Editorial service

- Swift Peer Review

- Reprints availability

- E-prints Service

- Manuscript Podcast for convenient understanding

- Global attainment for your research

- Manuscript accessibility in different formats ( Pdf, E-pub, Full Text, Audio)

- Unceasing customer service

Track the below URL for one-step submission https://juniperpublishers.com/online-submission.php 